\begin{abstract}
"Mircea cel Batran" Naval Academy Scientific Bulletin, Volume XX - 2017 - Issue 2
The journal is indexed in: PROQUEST / DOAJ / Crossref / EBSCOhost/ INDEX COPERNICUS/ OAJI / DRJI I

JOURNAL INDEX / I2OR / SCIENCE LIBRARY INDEX / Google Scholar / Academic Keys / ROAD Open Access I Academic Resources / Scientific Indexing Services I SCIPIOI JIFACTOR
\end{abstract}

\title{
THE MODERN HERO IN MILTON'S PARADISE LOST: GOD THE SON
}

\author{
Corina SANDIUC ${ }^{1}$ \\ ${ }^{1}$ Assistant Mircea cel Batran Naval Academy, ema sandiuc81@yahoo.co.uk
}

\begin{abstract}
The character of God the Son in Milton's Paradise Lost seems to have all the qualities of the modern hero: he is the deliverer, the godlike man, the provider of true liberty. The argument of the poem is based on a double parallel. The first one deals with the antithesis Christ - Satan, corresponding to the opposition between Heaven and Hell, their morals, contrasting councils and enterprises as well as their contrary ideals of heroism. The poem further develops with the contrast between the divine and human standards, between the earthly and heavenly man and the antithesis between the former's disobedience and loss of Paradise and the latter's recovery of Paradise through obedience. Nevertheless, more than a hero, God the Son seems to be the embodiment of a heroic archetype following the divine pattern of heroic virtue, as opposed to Satan's false heroic features and to Adam's worldly standards.
\end{abstract}

Key-words: God the Son, mercy, hero, epic.

Like many of his late Renaissance contemporaries, Milton was committed to the biblical themes accepting as absolute several religious premises. The scripture was for him the final arbiter of truth, and he understood the ancient and superhuman animosity between the good and evil forces to be replicated in the daily life of each Christian. Paradise Lost is firmly established in Christian doctrine. The center of Milton's narrative is the creation myth of the Israelites as seen through the eyes of a Protestant Christian. In this story, the original paradise perfection of the human existence is shattered by the disobedience of the first couple, Adam and Eve, to God's express prohibition. Because of the punishment God proclaims for this disobedience, the human beings and their descendants are punished with suffering and death.

The God of Milton's Paradise Lost is portrayed in the persons of God the Father and God the Son. If the Father is the cold embodiment of ideas, the Son is the one who converts them into actions. If God the Father is an expression of pure reason and justice, an image of the absolute monarch entangled in a struggle for power, the Son shows the more merciful aspect of God defined by his sacrifice. $\mathrm{He}$ is the one who provides mercy to temper the Father's justice.

The Son of God makes his entrance in an atmosphere of pure light, scattered with phrases of praise combined in a hymn describing the nature of God and Heaven:

"Hail holy light, offspring of Heav'n firstborn,

Or of th' Eternal Coeternal beam

May I express thee unblam'd? since God is light,

And never but in unapproached light"

$$
\text { (I, 1-4) }
$$

God the Son is the counterpart of God the Father, and the Father is bursting with pride in his Son:

Because thou hast, though Thron'd in highest bliss

[...] By Merit more then Birthright Son of God

Found worthiest to be so by being God

Farr more then Great of High;

(III, 305-11)

It is an ideal relationship in which the two complete and utterly understand each other. They have the same thoughts about the fate of man. As a consequence, the Son will do anything to please his Father:

Then with the multitude of my redeemd Shall enter Heaven long absent, and returne,

Father, to see thy face, wherein no cloud Of anger shall remain, but peace assur'd, (III, 260-3)

The Son of God is depicted according to the Christian tradition. He is the future incarnation of Jesus Christ, the one who offers to take on man's punishment by becoming himself human and suffering death by persecution and crucifixion, thereby saving him from death and Hell and providing hope for a better place in Heaven:

"so Man, as is most just

Shall satisfie for Man, be judg'd and die"

(III, 294-5).

When all of God's angels hesitated, He volunteered to die for man's sin, so that once 


\begin{abstract}
"Mircea cel Batran" Naval Academy Scientific Bulletin, Volume XX - 2017 - Issue 2
The journal is indexed in: PROQUEST I DOAJ / Crossref / EBSCOhost/ INDEX COPERNICUSI OAJI / DRJI I

JOURNAL INDEX / I2OR / SCIENCE LIBRARY INDEX / Google Scholar / Academic Keys / ROAD Open Access I Academic Resources / Scientific Indexing Services / SCIPIOI JIFACTOR
\end{abstract}

incarnated as a human, to derive Adam's punishment from his mother's lineage:

"And dying rise, and rising with him raise His Brethren, ransomd with his own dear life."

God's image as a dictator is emphasized in this sequence. He seems to be a partisan of inflicted pain as he outlines the sacrifice involved. The presentation of the sufferings implied has such an impact on the angels that no volunteer steps forward. Although stressing the Son's courage and commitment to the Father's cause, this episode presents the lack of courage of the celestial beings. In contrast, the courage and resolution of the rebel angels is highly emphasized.

In the Books VI and VII God sends forth his Son to accomplish a great mission. The first is a mission of war, to defeat the rebel angels and cast them out of Heaven. The second is a mission of peace, to create a new world and new creatures that will eventually fill the space in Heaven left by the fallen angels. In both, Messiah returns triumphant to his place in Heaven.

In Book VI, He is the warrior-defender of Heaven, sent by the Father on the third day of the battle to crush Satan. He rides in a spectacular chariot, facing Satan's army alone. The third day is symbolic of the period Jesus spent in the tomb in the Christian New testament. The Christian belief is that when Christ resurrected on the third day, he defeated death. In Milton's poem, Death is Satan's son; hence Satan's defeat is a direct correlation with Jesus' victory over death. God the Son, prince of Heaven, is correlated with Messiah, man's redeemer. He fights against the whole of Satan's army without any help from God's angels, the same way He faced crucifixion and death. When He passes by on his chariot, the torn up hills of Heaven are reconstructed and nature reassumes its order. In a macrocosmic sense, the Son is reordering what was chaos, anticipating the creation of earth and the way He will make mankind ordered, rational and good.

The element of politics is obvious in these passages. The battles between God and Satan echo the episodes of the Civil War waged by Charles the first against the Parliament. Milton describes God in a power struggle, while plotting military strategy with his Son. However, the main features of the Son are revealed by his love and mercy, both represented by his sacrifice. He is more heroic when He offers to lay down his life for the ransom of man:

Behold me then, me for him, life for life I offer, on me let thine anger fall
(III, 236-7)

His conquering death opens the door of Heaven to man. Although immortal, He came down from Heaven, becoming fully human while at the same time fully God, and experienced death. Through resurrection, death loses its grip over man; it is no longer a permanent state, but a transition to a new life:

\section{[...] then rising from his Grave The Realm it self of Stan long usurpt,}

(VII, 185-6)

In Book VII, Raphael tells the story of creation. Here the Son is sent out by his Father to carry out the miracle of Creation. Although Milton does not make the Son equal in power to the Father, Messiah is referred to during the act of creation as God. Book $X$ presents him as the merciful judge. After the Fall, He goes to Earth at God's request to pass judgment on the serpent, Adam and Eve. He pities the fallen couple, mercifully postpones their punishment of death. He understands that justice without mercy is revenge ("I shall temper so / Justice with Mercy"), and so becomes the good king, one that has as priority the happiness of his subjects. This is an attribute better stressed in Paradise Regained where He embodies the perfect moral human whom others aspire to emulate, but can only do so imperfectly.

If we compare the Son to Satan, a parallel may be drawn although the contrasts are profound. They both volunteer while others hang back and can have equal influence over the destiny of man. The difference lies in the fact that Christ offers to undertake the task of saving mankind while Satan would do anything to corrupt them and contradict God's will. Satan uses his volunteerism to glorify himself and intimidate others. At his presentation of the enterprise, the angels

"Dreaded not more th' adventure then his voice"

$$
\text { (II, 474). }
$$

The Son's consideration, on the other hand, is to please his Father, offering:

Filial obedience: as a sacrifice Glad to be offer'd, he attends the will Of his great Father.

$$
\text { (III, 269-70) }
$$

The Messiah achieves exaltation through humiliation, while Satan exalts himself above his peers. The first chooses to trade the form of God for the form of a servant, while the latter aspires to 


\begin{abstract}
"Mircea cel Batran" Naval Academy Scientific Bulletin, Volume XX - 2017 - Issue 2
The journal is indexed in: PROQUEST / DOAJ / Crossref / EBSCOhost/ INDEX COPERNICUS/ OAJI / DRJI I

JOURNAL INDEX / I2OR / SCIENCE LIBRARY INDEX / Google Scholar / Academic Keys / ROAD Open Access I Academic Resources I Scientific Indexing Services / SCIPIOI JIFACTOR
\end{abstract}

deity and scorns servitude. They are both voluntarily incarnate. If the Son keeps his God-like essence, in spite of the human shape, Satan's outfit is perfectly tailored to his hellish essence. $\mathrm{He}$ is doomed to always have Hell about him because "within him Hell / He brings." (IV, 20) Moreover, his unholy union with Sin and Death in the diabolical trinity is a parody of the divine trinity. Reason, Love, Light are replaced by lust in an irrational relationship outside God's grace.

J.M. Steadman considers God the Son to have all the qualities of the true hero. He is "the supremely heroic deliverer who alone can restore man's internal freedom through regeneration." ${ }^{1}$ As a teacher of righteousness and a martyr, Messiah enters the pattern of the "godlike man", more heroic than the warrior. He offers true freedom, "the freedom founded on obedience to the right reason." ${ }^{2}$ Saif Patel, on the other hand, considers that contrary to the other potential heroes of the poem, the Son did not necessarily experience a spiritual change, and believes that the ambiguity of Milton's hero was intentional. It seems that Milton "whishes to share his own heroism in composing such an epic to his culture - both English and Christian - by taking the reader on a trip through the consciousness of each of his constructed characters, exploring the different facets of freedom and responsibility." 3 It is exactly this ambiguity between premeditation and improvisation that makes Milton's work so interesting and the character of God so controversial.

Faced to the task of drawing us to God's point of view, Milton shocks by showing admirable qualities in Satan, who is seen as a hero mainly because he was portrayed with human attributes, such as: defiance, anger, regret, arrogance. He is extremely human-like, endowed with weaknesses and passions one can really relate to. The parts of the poem, which fully transcend the Parnassian style and deliver the most astonishingly powerful poetry consistently emerges from the part of those characters defying God. On the contrary, the poetry describing God and the angels is consistently uninspired, flat, Parnassian. The most obvious problem that results is that of anthropomorphism, of God sounding like a mortal vociferously defending his actions. Therefore, God cannot be said to be the hero of Paradise Lost, He is too devoid of inner conflict and of any resemblance to human nature to be a convincing literary figure. In transforming the divine beings into palpable characters, Milton also makes Satan sound like any earthly proponent of freedom. Rebellions against a dictator resemble the extraordinary revolutionary actions of a hero, and

\footnotetext{
${ }^{1}$ J. M. Steadman, 1986, p. 182.

2 Idem.

${ }^{3}$ S. Patel, 2004.
}

would normally be a sympathetic one. Usually, to Christians at least, Heaven is rightfully a benevolent dictatorship synonym of goodness and love. But as a character in a story, God cannot easily inspire the reader to sympathise or identify with Him.

The contradictions that haunt Paradise Lost are the main aspect which renders its modernity. In its treatment of the norms of the "heroic", Milton established a distinctive heroic diction and initiated a fertile debate about who was the "hero" of his epic. Paradise Lost does not have a hero in the classical sense. There is a permanent tension between the classical and Christian elements, until the classical tradition is gradually absorbed and replaced by the Christian. For this reason, there is something deeply paradoxical and problematic about Milton's characters, and once with the critical issues they raised, very different facets of the heroic came into open. The Christian critics consider God in his omnipresence or the merciful Messiah as liable heroes, while others suggest that Adam is the hero or Adam and Eve together. Moreover, the romantic period critics believe that Milton does not manage to deliver the meaning he consciously intended to deliver, and that he unconsciously made Satan the centre of interest and the most fascinating character of his poem. What finally becomes clear is that the hero in Paradise Lost is, in spite of the epic tradition, a spiritual hero. Thus, at the end of the poem, Adam and Eve, reconciled to their destiny, begin a new life which is both a battle and journey. 
"Mircea cel Batran" Naval Academy Scientific Bulletin, Volume XX - 2017 - Issue 2 The journal is indexed in: PROQUEST I DOAJ / Crossref / EBSCOhost/ INDEX COPERNICUSI OAJI / DRJI I JOURNAL INDEX I I2OR / SCIENCE LIBRARY INDEX / Google Scholar / Academic Keys / ROAD Open Access I Academic Resources / Scientific Indexing Services / SCIPIOI JIFACTOR

\section{BIBLIOGRAPHY}

[1] MILTON, John (1674). Paradise Lost; A Poem in Twelve Books (II ed.). London: S. Simmons. https://www.dartmouth.edu/ milton/reading_room/contents/text.shtml\#paradiseLost

[2] STEADMAN, John M. (1986). "Paradise Lost", in: The Penguin History of Literature. English poetry and Prose 1540-1674. London: Penguin Books.

[3] PATEL, Saif (2004). "Paradise Lost: A Revival of the Spirit", in: Luminarium: Anthology of English Literature. http://www.luminarium.org/sevenlit/milton/patel2.htm 